\title{
Organization of project activities of students in the additional education system
}

\author{
Zhanna Venediktovna Smirnova*, Olga Takhirovna Chernei, Lyubov Ivanovna Kutepova, \\ and Zhanna Vladimirovna Chaikina \\ Minin Nizhny Novgorod State Pedagogical University, Faculty of Management and Social and \\ Technical Services, Nizhny Novgorod, Russia
}

\begin{abstract}
Additional education, along with school education, is becoming an important link in the general education system, which guarantees the formation of the student's personality and his or her early professional selfdetermination. For this reason, all the methods and techniques used by teachers of additional education in their practice should form competencies that meet the requirements of modern society. Nowadays, with a wide variety of forms in the additional education system, project activities are one of the most demanded and innovative areas. This article reveals the main goal of the study of theoretical substantiation and experimental verification of the effectiveness of the pedagogical conditions for organizing the project activities of students in the additional education system. The methodological basis of the study is as follows: the main provisions of the personality-oriented approach; theoretical foundations of the competency-based approach; the provisions of the activity approach. The scientific novelty of the research lies in the fact that a complex of pedagogical conditions was developed that is necessary and sufficient for the effective implementation of project activities in an additional education institution for children. The result of the research is as follows: the developed theoretical provisions and conclusions enable to modernize the organization and content of project activities in the additional education system; a set of pedagogical conditions for implementing project activities of students in the additional education system has been developed. The research results can be used in the work of additional education institutions for children, as well as in other educational institutions.
\end{abstract}

Keywords: additional education, project activities, student

\section{Introduction}

At present, in the context of the rapid development of scientific and technological progress, which has changed the socio-economic sphere of Russia, the education system is undergoing a number of significant changes: the content of education is being transformed; new forms and methods of teaching are being introduced; the list of knowledge, skills and abilities is being revised. All these changes in the field of education are aimed at the

\footnotetext{
* Corresponding author: z.v.smirnova@mininuniver.ru
} 
transition from the traditional paradigm of learning to a competency-based one. The essence of this paradigm lies not in the student's mastery of the totality of knowledge and skills, but in the development of competencies aimed at achieving subject, interdisciplinary and personal learning outcomes.

The above-mentioned innovations affected the entire education system, including the system of additional education for children. Additional education, along with school education, is becoming an important link in the general education system, which guarantees the formation of the student's personality and his or her early professional selfdetermination. For this reason, all the methods and techniques used by teachers of additional education in their practice should form competencies that meet the requirements of modern society. Nowadays, with a wide variety of forms in the additional education system, project activities are one of the most demanded and innovative areas.

The traditional methods used today in the additional education system cannot fully reveal the full potential of the student's personality. The methods that help to prepare students for choosing their future professional path, help them to adapt to rapidly changing technologies in modern society, and develop skills of creative thinking and independence come to the aid of such teaching methods. One of these methods is project activity [1].

\section{Methods}

In the process of researching the organization of project activities in additional education institutions, the works of authors studying these problems were examined. From the work by N.V. Matyash, "project activity is a type of activity that contains a complex of elements of play, educational, cognitive, reflective, research, and creative activity" [2].

The interest in project activities has noticeably increased in recent years. This can be confirmed by the works of many scientific researchers. A great contribution to the study of approaches to organizing teaching project activities in an educational institution was made by such researchers as: V.G. Veselova, O.R. Kozlova, V.M. Monakhov, et al. The works by E.M. Borisova, V.V. Guzeeva, N.Yu. Erofeeva, V.V. Kopylova, N.Yu. Pakhomova, and I. D. Chechel are devoted to the study of the basics of project activities.

The essence of project activity was most vividly and fully revealed by such scientists as I.A. Kolesnikova and A.S. Sidenko. In their publications, they revealed the essential characteristics of project activities, identified the basic stages of planning, studied the possibilities of developing the students' personalities through project activities [3].

The project activities of students at school have been comprehensively studied up to date. The historical prerequisites for the emergence of the project method were reflected in the works by L.I. Bogomolova and R.B. Vendrovskaya. A number of researchers have considered the pedagogical potential of project activities through the formation of certain personal characteristics of a student. They saw the potential of students' project activities in the development of their educational and cognitive interest (O.A. Grebennikova), in the formation of their information culture (I.N. Bukhtiyarova), as well as in the formation of independence and creative initiative (M.L. Serdyuk, T.V. Shevtsova) [4].

The project activities of students in the additional education system have been little studied by now. It was studied as a means of vocational guidance of students in mastering computer technologies (A.V. Mayatin), as one of the methods of their creative activity in a children's association (Yu.F. Sazonov). However, the possibilities of organizing project activities of students in the additional education system and the conditions for implementing these possibilities have not yet been studied.

Thus, the relevance of the identified research problem is determined by the contradictions between: 
- a high level of theoretical elaboration of the problem of students' project activities in the educational process of the school and its insufficient knowledge in the additional education system;

- the orientation of the education system to the individual development of students and the incomplete study of the capabilities of teachers of additional education in creating conditions for this $[5,6]$.

Taking into account the urgency of the problem and the above-mentioned contradictions, the research topic was formulated: "Organization of project activities of students in the additional education system".

\section{Results}

The experimental work was conducted at the municipal budgetary institution of additional education "Center for children's creativity of the Avtozavodskii district" (MBI AE "CCC of the Avtozavodskii district") of the city of Nizhny Novgorod from October 2020 to April 2021.

The purpose of the experimental research is to test the effectiveness of the selected conditions for organizing the project activities of students, as well as to test and introduce them into the activities of the "Robotics" club. This goal determined the process of the experimental research [7].

The experimental study took place in three stages:

I stage (October-November 2020): ascertaining.

II stage (December-February 2021): formative.

III stage (March-April 2021): control.

In the ascertaining stage of the experimental study, 15 students of the "Robotics" club participated ( 10 boys and 5 girls. The age of the children varied from 9 to 14 years).

The ascertaining stage was conducted in order to identify the initial level of students' readiness to organize project activities. During this stage, the following tasks were solved:

- to diagnose the actual level of students' readiness to organize project activities;

- to evaluate the experience of teachers of additional education in applying project activities;

- to study the pedagogical possibilities of an association in organizing project activities.

The first thing that needed to be checked at the ascertaining stage of the experimental study was the initial level of students' readiness to organize project activities. For this, a survey was conducted among the students of the "Robotics" club [8].

The results of all stages of the experiment were diagnosed using the control and evaluation apparatus developed by the author, which includes the following methods: conversation, observation, questioning, monitoring, and study of the products of students' activities.

The leading direction in the study was to identify the level of students' readiness to organize project activities in an additional education institution. To achieve this goal, a questionnaire was developed, which enabled to find out from students, using pre-prepared questions, their involvement in project activities. The results of the ascertaining experiment on diagnosing the level of students' readiness for project activities can be presented in the form of a diagram in Figure 1. 


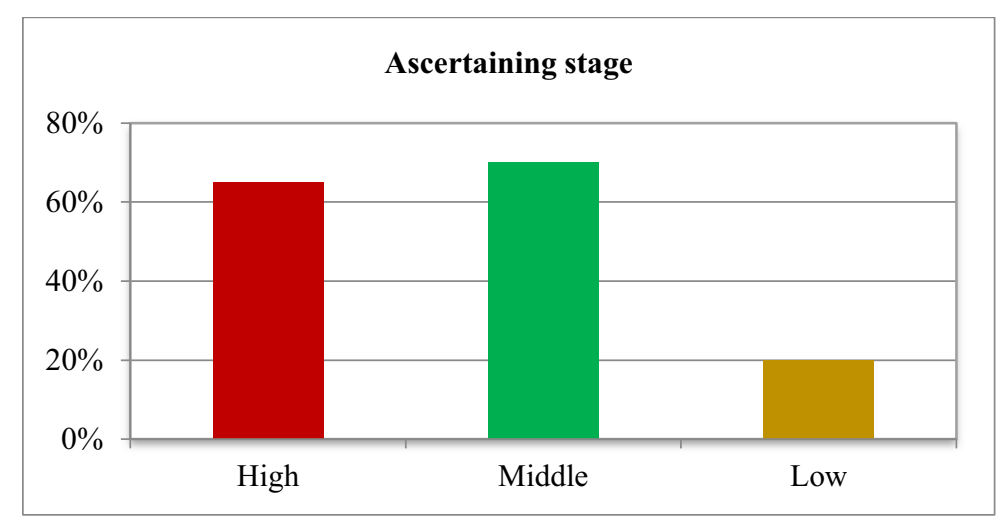

Fig. 1. Levels of students' readiness for project activities.

The results of the diagram show that a large percentage of students have poor preparation for organizing project activities (65\%), average level $(70 \%)$ and high level $(20 \%)$. This suggests that the majority of students do not have a clear idea of the subject of project activities. They also do not have a general idea of how to correctly formulate conclusions and the problem, use the information found, and find ways to solve the problem [9].

Thus, the results obtained at the ascertaining stage of the experimental study were unsatisfactory. It was obvious that little attention was paid to project activities in the additional education institution. Therefore, the author proposed to create an additional general educational (general developmental) program for the "Robotics" club, which would improve the level of development of project skills among students. Such project skills can help to plan the professional path, as well as increase the competitiveness of an individual in the labor market.

The formative stage of the experiment was built taking into account the selected groups of pedagogical conditions and stages of organizing project activities of the students in the "Robotics" club.

The effectiveness of the developed program of the "Robotics" club can be judged on the basis of the data that were obtained in the process of the ascertaining and formative stages of the experimental research.

After approbation of the program of the "Robotics" club, at the control stage, positive dynamics was traced, that is, the level of development of skills in project activities relatively increased, which indicates the effectiveness of the implemented pedagogical conditions. The results of the control stage of the study can be presented in the form of a diagram in Figure 2. 


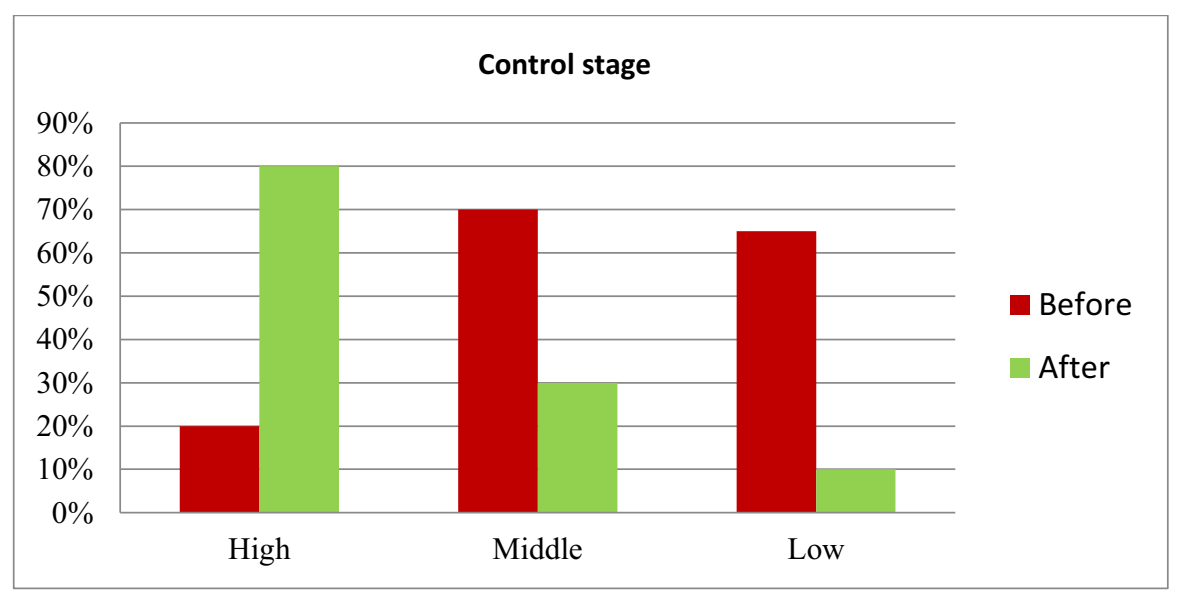

Fig. 2. Levels of development of skills in project activities.

The diagram clearly shows what level of students' readiness for project activities was before the club's program was approbated and what it became after it. After the program was approbated, the students with a high level of development of skills in project activities accounted for $80 \%$, an average level $-30 \%$, and a low level - only $10 \%$ of the total.

The observation enabled to reveal that implementing project activities allowed students to logically and competently build a plan for performing their actions in the process of work, correctly formulate the goals and objectives of the project work, independently search for the necessary information, as well as formulate a problem.

\section{Discussion}

The leading direction in the experimental research was identifying the level of students' readiness to organize project activities in an additional education institution. To achieve this goal, a questionnaire was developed, which enabled to find out from students, using preprepared questions, their involvement in project activities. The questionnaire, consisting of 13 questions, was created using the google forms platform. Some questions contained only the choice of one answer, others involved the choice of several statements. Each question was aimed at identifying a specific goal [10].

Based on the data obtained as a result of the questionnaire, it can be concluded that the readiness for project activities of students is at an average ( 7 students) and a low level (6 students). There are general ideas about project activities, but they are not yet formed and vague. Only two students had a high level. As it turned out during the conversation, they were activists and participants in multiple school projects, as well as projects held outside the school [11].

The results obtained at the ascertaining stage of the experimental study were unsatisfactory. It was obvious that little attention was paid to project activities in the additional education institution. Therefore, the author proposed to create an additional general educational (general developmental) program for the "Robotics" club, which would improve the level of development of project skills among students. Such project skills can help to plan a professional path, as well as increase the competitiveness of an individual in the labor market.

The technical orientation of the program was not chosen by chance, since in the classes of this orientation there is a good opportunity to implement project activities. Such programs are aimed, first of all, at developing students' interest in engineering and 
information technologies, as well as in scientific-research and constructive activities. Here it can be checked how the project activities are implemented taking into account the created pedagogical conditions. In the process of the activities, observing, or by the result of the finished product, it is possible to determine whether the program has effectively coped with its set goal.

After approbating the program of the "Robotics" club, at the control stage, positive dynamics was traced, that is, the level of development of skills in project activities relatively increased, which indicates the effectiveness of the implemented pedagogical conditions [12].

The diagram clearly showed that there were $80 \%$ of students with a high level of development of skills in project activities, with an average level $-30 \%$, with a low level only $10 \%$ of the total.

The results obtained at the control stage of the experimental study showed a positive trend associated with an increase in changes in the levels of development of skills in project activities. This was facilitated by organizing the project activities of students. The revealed pedagogical conditions in the process of analysis of scientific and pedagogical literature contributed to activating the project activities of students. These conditions are effective and can be used by teachers of additional education in their work when organizing project activities.

\section{Conclusion}

The study of the problem of organizing the project activities of students in the additional education system confirms the hypothesis of the study and gives the basis to formulate a number of generalized conclusions of a theoretical and practical nature.

The results obtained at the control stage of the experimental study showed a positive trend associated with an increase in changes in the levels of development of skills in project activities. This was facilitated by organizing the project activities of the students. The revealed pedagogical conditions in the process of analysis of scientific and pedagogical literature contributed to the activation of the students' project activities. These conditions are effective and can be used by teachers of additional education in their work when organizing project activities.

When creating conditions for organizing project activities, in the additional education system, it is required to study scientific research in this area in detail, focus on the age composition of the group of students, on the orientation of the association in an additional education institution, as well as on the modern demands of society and the state for education.

\section{References}

1. T.E. Vedeneeva, Proektnaya tekhnologiya kak odin iz faktorov postroeniya sistemy lichnostno-orientirovannogo obrazovaniya v shkole [Project technology as one of the factors in building a system of personality-oriented education at school] (YUNIT, Moscow, 2016)

2. N.E. Saurenko, Prof. Edu. 1, 44-47 (2014)

3. V.A. Gorskii, Add. Edu. 3, 29-35 (2003)

4. V.A. Berezina, Sistema dopolnitelnogo obrazovaniya detei kak sredstvo ikh tvorcheskogo razvitiya [The system of additional education for children as a means of their creative development] (Prosveshchenie, Moscow, 2016) 
5. S.I. Kuznetsova, Edu. Qual. Manag. 7, 80-84 (2013)

6. N.E. Saurenko, Proektnaya deyatelnost kak sredstvo formirovaniya tvorcheskoi aktivnosti uchashchikhsya kolledzha [Project activity as a means of forming the creative activity of students]. Abstract of PhD Thesis in Pedagogy (Moscow, 2004)

7. I.S. Sergeev, Kak organizovat proektnuyu deyatelnost uchashchikhsya: prakticheskoe posobie obshcheobrazovatelnykh uchrezhdenii [How to organize the project activities of students: a practical guide of general education institutions] (ARKTI, Moscow, 2016)

8. O.A. Severina, Proektnaya deyatelnost uchashchikhsya [Project activities of students] (Uchitel, Moscow, 2015)

9. Z.V. Smirnova, et al., Lect. Notes in Networks and Sys. 73, 371-379 (2020)

10. Z.V. Smirnova, et al., Lect. Notes in Networks and Sys. 73, 1065-1072 (2020)

11. Shalin, M.I. Organizatsionno-pedagogicheskie usloviya razvitiya konkurentosposobnosti lichnosti shkolnikov [Organizational and pedagogical conditions for developing competitiveness of schoolchildren's personalities] (Renome, Saint Petersburg, 2013)

12. V.V. Tigrov, Pedagogika, 10, 43-48 (2013) 